\title{
The Simulation of Influence of Quenching Temperature on Properties of Bearing Rings
}

Martin Brezničan ${ }^{1}$, Peter Fabian ${ }^{1}$, Jozef Meško ${ }^{1}$, Mário Drbúl ${ }^{2}$

${ }^{1}$ Department of Technological Engineering, Faculty of Mechanical Engineering, University of Žilina, Univerzitná 8215/1, 01026 Žilina, Slovak Republic. martin.breznican@fstroj.uniza.sk

${ }^{2}$ Department of Machining and Manufacturing Technology, Faculty of Mechanical Engineering, University of Žilina, Univerzitná 8215/1, 01026 Žilina, Slovak Republic.

Roller bearings are a very important part of modern machineries and equipments. They have a significant impact on the smooth running, reliable performance and durability. Replacing worn or damaged roller bearings often require extensive disassembly of the machine and the costs often exceed the price of the replaced bearings. There is an influence of the correct bearing construction and dimensional accuracy on the durability, but the grade and quality of used steel and its heat treatment are very important, too. Tempering is an important chapter. Tempering has the effect to modifying the properties of martensite after quenching and transformation of residual austenite, which is related to the change of bearing rings dimensions, growth, roundness and hardness. Decrease in hardness of bearing steel is associated with a reduction in the basic dynamic load rating of rolling bearings and thus durability. In this article there is analysed the influence of quenching and tempering on their mechanical properties after heat treatment. There was also used simulation software to verify the possibility of modeling of bearing rings quenching.

Keywords: bearing rings, 100Cr6 steel, quenching, tempering, simulations

\section{Acknowledgement}

The experimental works and measurements were made with the help of Ministry of Education of the Slovak republic, grants VEGA no. 1/0186/09 and KEGA no. 054ŽU-4/2012 - responsible researcher: Prof. Jozef Meško, MSc., PhD.

\section{References}

[1] BESWICK, J. (2002): Bearing Steel Technology, ASTM, West Conshohocken.

[2] DURAND-CHARRE, M. (2004). Microstructure of Steels and Cast Irons. Berlín: Springer-Verlag Berlin Heidelberg New York. 399 p. ISBN 978-3-540-20963-8

[3] HAKAN GÜR, C., PAN, J. (2008). Handbook of Thermal Process Modeling of Steels. pp. 342 - 380, Taylor \& Francis Group LLC, Boca Raton.

[4] KANG, S. H. - IM, Y. T. (2007). Thermo-elasto-plastic finite elements analysis of quenching process of carbon steel. Journal of Materials Processing Technology, No. 192 - 193, pp. 381 - 390.

[5] JERSÁK, J., et al. (2009). The Integrity of the Surface after Milling of Quenched Bearing Steel. Manufacturing Technology, No. 4. pp. 13 - 20. ISSN 1211-4162.

[6] Llewellyn D. T., HUDD, R. C (1998). Steels: Metallurgy and Applications. $3^{\text {rd }}$ edition. Oxford: ButterworthHeinemann, 1998. 389 p. ISBN 0-7506-3757-9

[7] MARTIENSSEN, W., WARLIMONT, H. (2005). Springer Handbook of Condensed Matter and Materials Data. Berlin: Springer-Verlag Berlin Heidelberg, New York. 1120 p. ISBN 978-3-540-44376-6.

[8] PANDA, A. et al. (2011). Optimization of heat treatment bearing rings with goal to eliminate deformation of material. The Chemical Sheets, No. 16/2011, pp. $459-467$.

[9] PEREZ, $\mathrm{M}$ et al. (2009). Microstructural evolution of martensitic 100Cr6 bearing steel during tempering. Acta Materialia, Vol. 57, No. 11, pp. 3171-3180.

[10] SKOČOVSKÝ, P. et al. (2000). Construction Materials. Žilina: EDIS, 2000. 338 p. ISBN 20-7100-608-4.

[11] TOTTEN, G. E., BATES, C. E., CLINTON, N. A. (1992). Handbook of Quenchants and Quenching Technology. ASM International.

[12] URGELA, D. et al. (2012). Production of casting moulds by patternless process. Advanced manufacturing and repair technologies in vehicle industry: 29th international coloquium: Žilina, pp. 199-207. ISBN 978-80-554-0533-9.

[13] VANDER VOORT, G. F. (1991). Atlas of time-temperature diagrams for irons and steels. ASM International. 